\title{
NEW UZBEKISTAN AND ELECTION LEGISLATION
}

\author{
Dr. Qahramon S. Tursunov
}

Associate Professor, Phd Bukhara State Medical Institute Bukhara, Uzbekistan

\section{ABSTRACT}

The system of state power in Uzbekistan is based on the principle of separation of powers into legislative, executive and judicial powers. The Oliy Majlis acts as the legislative branch of power in the Republic of Uzbekistan. It represents the main political parties, all social strata and socio-political forces of society. In general, the parliament represents the people of Uzbekistan. Only the Oliy Majlis elected by him and the President of the Republic can speak on behalf of the people of Uzbekistan.

KEYWORDS: - Third Renaissance, political parties, the parliament represents, legislative, the comprehensive support, election campaign.

\section{INTRODUCTION}

Today, when the powerful potential of our people is being fully realized, the foundation of a new Renaissance era - the third Renaissance is being laid in Uzbekistan. After all, today's Uzbekistan is not yesterday's Uzbekistan. And our people are not the same as they were yesterday. " These thoughts were voiced by President Shavkat Mirziyoyev at the ceremony dedicated to the 29th anniversary of the independence of the Republic of Uzbekistan. At the same time, the mention of the phrase "New Uzbekistan" on a global scale testifies to the recognition that in recent years we have entered a completely new stage of development - a stage of tremendous transformations and achievements.

\section{THE MAIN RESULTS AND FINDINGS}

As part of the large-scale and consistent reforms carried out in the country aimed at creating a new democratic and free Uzbekistan, special attention is paid to the implementation of the constitutional principle of democracy, ensuring the participation of citizens in government and society, as well as improving electoral legislation. For democratic and fair elections are considered the most important and necessary condition for democracy.

Today, the country pays great attention to improving the educational sphere, especially the comprehensive support of representatives of science and education. Intellectual wealth is 
CURRENT RESEARCH JOURNAL OF PHILOLOGICAL SCIENCES 2(12):

49-51, December 2021

DOI: https://doi.org/10.37547/philological-crjps-02-12-10

ISSN 2767-3758

(C)2021 Master Journals

Crossref do

gil Google

Accepted06 ${ }^{\text {th }}$ December, 2021 \& Published $11^{\text {th }}$ December, 2021

revered, which is directly related to the history, character, mentality, age-old values and dreams of our people. And here the firm conviction, one might say, the life principle of the President - "The greatest wealth in the world is the knowledge and profession acquired in his youth" is important here. According to the current electoral code of the Republic of Uzbekistan, the President of the Republic of Uzbekistan is elected for a term of five years, and the same person cannot be President of the Republic of Uzbekistan for more than two consecutive terms. A citizen of the Republic of Uzbekistan not younger than thirty-five years old, fluent in the state (that is, Uzbek) language, permanently residing in the territory of Uzbekistan for at least ten years immediately before the elections can be elected as the President of the Republic of Uzbekistan. They do not have the right to participate in elections and, accordingly, are not subject to registration as candidates for the President of the Republic of Uzbekistan previously convicted of intentional crimes, as well as professional ministers of religious organizations and associations

A political party has the right to nominate a candidate, provided that it is registered by the Ministry of Justice of the Republic of Uzbekistan no later than four months before the day of the announcement of the start of the election campaign. Nomination of candidates starts 65 days before the elections and ends 45 days before the elections. The nomination of candidates is carried out only by the supreme bodies of political parties, and one political party can nominate only one candidate. A political party can nominate a candidate only from among its members, or a non-party candidate. Thus, independent and non-partisan candidates cannot, according to the law, independently nominate their candidacy, and this requires becoming a member of one of the officially registered parties and nominating themselves only with the support and approval of the leadership of these parties. This point is often criticized by experts, political scientists, international observers and organizations, as well as human rights defenders, oppositionists and dissidents. As of January 2021, only five political parties are officially registered in Uzbekistan. These are: the Liberal Democratic Party of Uzbekistan, the Democratic Party "Milliy Tiklanish" (National Revival), the Social Democratic Party "Adolat" (Justice), the People's Democratic Party of Uzbekistan and the Ecological Party of Uzbekistan.

\section{Conclusion}

The voting process on October 24, 2021 was observed by representatives of international organizations: CIS, SCO, OSCE, OIC and others. Almost 1,500 journalists from different countries have been accredited for the election campaign.

The results of the presidential elections in Uzbekistan showed that the political leadership provides the republic with internal stability.

The presidential elections in Uzbekistan were held without violations and in accordance with national legislation, were legitimate and democratic.

\section{REFERENCES}

1. Турсунов, К. (2013). Швейцария: оценки хода государственного и общественного строительства в независимом узбекистане. Fuqarolik jamiyati. Гражданское общество, 10(3), 83-86.

2. Турсунов, К. (2010). БЕЛЬГИЯ: ОСВЕЩЕНИЕ ОПЫТА ФОРМИРОВАНИЯ ОСНОВ ГРАЖДАНСКОГО ОБЩЕСТВА В УЗБЕКИСТАНЕ. Fuqarolik jamiyati. Гражданское общество, 7(2), 91-94.

3. Турсунов, К. (2014). ЛАТВИЯ: ОЦЕНКИ РЕАЛИЗАЦИИ ГОСУДАРСТВЕННОЙ 
CURRENT RESEARCH JOURNAL OF PHILOLOGICAL SCIENCES 2(12):

49-51, December 2021

DOI: https://doi.org/10.37547/philological-crjps-02-12-10

ISSN 2767-3758

(C)2021 Master Journals

Crossref d

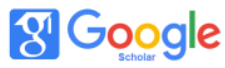

Accepted06 ${ }^{\text {th }}$ December, 2021 \& Published $11^{\text {th }}$ December, 2021

МОЛОДЕЖНОЙ ПОЛИТИКИ В

НЕЗАВИСИМОМ УЗБЕКИСТАНЕ. Fuqarolik jamiyati. Гражданское общество, 11(1), 6164.

4. Sodikovich, T. K. (2020). HISTORY OF THE BUKHARA STATE MEDICAL INSTITUTE NAMED AFTER ABU ALI IBN SINO. Наука, техника и образование, (11 (75)).

5. Sodikovich, T. K. (2021). EUROPE AND THE COMMONWEALTH OF INDEPENDENT STATES. Наука, техника и образование, $(6$ (81)), 42-44.

6. Турсунов, К. (2009). Германия: университетские исследования формирования гражданского общества в Узбекистане. Fuqarolik jamiyati. Гражданское общество, 6(2), 77-80.

7. Турсунов, К., \& Бафоев, Ф. (2008). К вопросу становления, функционирования и развития парламентской оппозиции. Fuqarolik jamiyati. Гражданское общество, 5(1), 53-58.

8. Турсунов, К. (2011). Великобритания: изучение опыта формирования основ гражданского общества в Узбекистане. Fuqarolik jamiyati. Гражданское общество, 8(3), 89-92.

9. Azizovna, A. Z. (2021). CULTURE OF TURKESTAN IN THE SECOND HALF OF THE 19 CENTURY. Berlin Studies Transnational Journal of Science and Humanities, 1(1.5 Pedagogical sciences).

10. Чориева, М. А. (2020). Экономика и денежное обращение (монеты) в Бухарском эмирате при мангытах (на рубеже 19-20 веков). Наука, техника и образование, (5 (69)), 53-56.

11. Azizovna, A. Z. (2020). Religious and Mystic Views of Ahmad Donish. Electronic Research Journal of Social Sciences and Humanities, 2, 273-276.

12. Ахмедова, 3. А., \& Чориева, М. А. (2020).
ТРУД АХМАДА ДОНИША «ИСТОРИЯ МАНГИТСКИХ ГОСУДАРЕЙ» КАК ЦЕННЫЙ ИСТОЧНИК ПО ИСТОРИИ БУХАРСКОГО ХАНСТВА ВТОРОЙ ПОЛОВИНЫ ХVIIIПЕРВОЙ ПОЛОВИНЫ ХІХ ВВ. Наука, техника и образование, (11 (75)).

13. Чориева, М. А. (2020). СОЦИАЛЬНОЭКОНОМИЧЕСКОЕ, ПОЛИТИЧЕСКОЕ ПОЛОЖЕНИЕ БУХАРСКОГО ЭМИРАТА В КОНЦЕ XIX ВЕКА. Наука, техника и образование, (11 (75)).

14. Azizovna, A. Z. (2021). THE ROLE OF TEACHING PHILOSOPHY IN MEDICAL UNIVERSITY. Наука, техника и образование, (6 (81)), 44-48.

15. Ахмедова, 3. А. (2018). Астрономические взгляды Ахмада Дониш. Вестник науки и образования, (11 (47)).

16. Ахмедова, 3. А. (2020). HUMAN BEING IN THE WORKS OF MEDIEVAL THINKERS. Новый день в медицине, (4), 115-118.

17. Ахмедова, 3. А. (2021). ХІХ АСРНИНГ ИККИНЧИ ЯРМИДА ТУРКИСТОН ЎЛКАСИ МАДАНИЯТИ. ВЗГЛЯД В ПРОШЛОЕ, 4(7).

18. Сагикызы, А., Шуршитбай, М., \& Ахмедова, 3. (2021). UPBRINGING AND EDUCATION AS FACTORS OF HUMAN CAPITAL DEVELOPMENT. Адам әлемі, 88(2), 18-25.

19. Ахмедова, 3. А., \& Турсунов, К. С. (2020). Интеграционный процесс в рамках Европейского союза. Наука, техника и образование, (5 (69)), 49-52.

20. Стариков А.А. Фирдоуси и его позма "Шахнаме".-Фирдоуси. Шах-намс, т.1.-М.:Наука, 1957, c.529-530. 